Тетяна Кушнірова

ORCID: https://orcid.org/0000-0001-9426-7184

Максим Домаренко

ORCID: https://orcid.org/0000-0003-1930-7312

DOI 10.31558/1815-3070.2020.40.2.12

УДК 81’255.4:81'373.2]:001.946

\title{
ОСОБЛИВОСТІ ПЕРЕКЛАДУ ВЛАСНИХ НАЗВ У ВІДЕОГРІ «DОТА 2»
}

У статті трунтовно і всебічно аналізуються власні назви у локалізації відеогри «Dota 2», а саме переклад онімів з англійської мови украӥнською. Власні назви розглядаються як філологічна категорія, простежуються особливості використання власних назв у відеоіграх, їхні генеза та функиії, досліджуються перекладацькі трансформації під час перекладу онімів у відеогрі. зокрема назв локацій, імен головних героїв тощо. У статті зроблено висновок про доиільність перекладаџьких трансформащій у грі, щуо впливає на якість програмного продукту. У роботі продемонстровано різні способи перекладу власних назв, увага закцентована на адекватності перекладу відеогри українською мовою та адаптованості локалізацій для украӥнського ринку.

Ключові слова: Dota 2, локалізачія, відеогра, власні назви, транскрибування, транслітерайія.

Наразі все очевиднішими у сучасному світі стають тенденції до глобалізаціï. Один із аспектів цього процесу - необхідність створення локалізацій пр ог рамних продуктів, зокрема й відеоігор, різними мовами світу. Особливі труднощі під час створення таких локалізацій викликають власні назви, які відбивають колорит певної культури і репрезентують новий об'єкт. У статті ця проблема пр езентується на прикладі відеоігор («Dota 2»), які, порівняно з іншими видами розважального контенту, зародилися недавно, у другій половині ХХ століття, а тому мають значний потенціал для проведення подальших досліджень. Це і визначає актуальність нашого дослідження.

На сьогодні досить складно знайти наукові праці, присвячені проблемі перекладу власних назв у різних жанрах ігрового контенту. Дещо важчим є пошук таких праць, які стосуються відеоігор. Зокрема дослідниця А. В. Домніна на конкретних прикладах доволі вдало демонструє важливість адекватного пер екладу власних імен. Цікавими є дослідження А. Р. Рюкової та Е. А. Філімоно вої, де проаналізовано російськомовну локалізацію відеогри «The Elder Scrolls V: Skyrim» для виявлення найбільш частотних способів пер екладу власних назв . Науковиці дійшли висновку, що перекладачі мализа мету «збереження оригінальної форми і звучання певних лексичних одиниць» (Рюкова, Филимонова 971-972).

Хоча у перекладознавстві уже і $є$ наукові розвідки, що стосуються цієї проблеми, проте на матеріалі відеогри «Dota 2» ще не було здійснено досліджень у сучасній філологічній науці. Унікальною нашу роботу робить той факт, що локалізації відеоігор українською мовою є явищем рідкісним (через економічну невиправданість), тому таких праць досить мало. Однак, індустрія відеоігор зростає значними темпами, тому дослідження перекладу англомовних власних

(C) Кушнірова Т., Домаренко М., 2020 
назв українською мовою є своєчасним і затребуваним явищем. Отже, метою нашої статті є аналіз способів перекладу власних назв в локалізації відеогри «Dota 2» та дослідження якості наявного продукту.

На сьогодні індустрія відеоігор за своєю популярністю впевнено займає домінантні позиції. Лише за 2019 рік світовий об' єм ігрового ринку склав білыш ніж 120 млрд доларів («2019 Year in review»). Наприклад, у США, одного 3 лідерів у цій галузі, на момент 2018 року 65 \% дорослих людей грали у відеоігр и, a у $75 \%$ сімей є хоча б одна людина, яка грає у відеоігри («2019 Essential Facts»).

Відеогра «Dota 2» є продовженням відеогри «Dota» (2003 рік), яка була користувацькою модифікацією для стратегії в реальному часі «Warcraft III: Reign of Chaos» і iï доповнення, «Warcraft III: The Frozen Throne». «Dota 2» стала доступною для бета-тестування у 2011 році і «вийшла» на ринок у 2013 році. У грі беруть участь дві команди по 5 гравців, кожний контролює свого персонажа, який з часом розвивається, отримує нові навички та купує або знаходить певні предмети. Метою гри є знищення ключової споруди супротивника. Робота над україномовною локалізацією гри була розпочата у 2013 році, і за тр и р оки декількома десятками волонтерів було перекладено більш ніж 450000 слів. Повністю переклад був завершений у 2016 році (за винятком нових оновлень гр и, які необхідно перекладати після їхнього виходу). (Завершено українську л окалізацію Dota 2).

Існує певна різниця між локалізацією і iі перекладом. Локалізація - це лінгвістична та культурна адаптація цифрового контенту до вимог та особливостей закордонного ринку, а також надання послугі технологій для управління багатомовністю у цифровому глобальному інформаційному потоці (Schäler 157). Саме на цьому етапі відеогра підлаштовується під культурні особливості та законодавчі вимоги певного ринку, щоб цільова аудиторія отримала вр аження, що гра була створена саме для них.

Переклад є однією зі складових частин локалізації (іншими є адаптація шрифтів; забезпечення правильного для певної мови відбиття дати, одиниць вимірів; створ ення нових текстур для перекладу графічних написів тощо) і стає лише структурним складником наповнення контенту.

Під час перекладу надзвичайно важливою є правильність перекладу вла сних назв, які необхідно передати належним чином, що може викликати помітні складнощі. Загалом, власна назва або ж онім - це «слово, словосполучення чи речення, яке служить для виділення іменованого ним об 'єкта серед інших о б 'єктів, його індивідуалізації та ідентифікації» (Подольская 91). Кожен онім несе в собі дані стосовно особливостей названого об' єкта чи явища; моменту історії, коли він виник; етносу, який його вигадав; мови, в якій він зародився тощо.

У суспільстві загалом і у відеоіграх зокрема оніми виконують роль певних мар керів. Вони несуть лаконічний опис певного персонажа, місця, явища тощо . Добре підібрана власна назва стає важливим інструментом у руках автора і може допомогти розкрити всю суть і характер героя ще до того, як гравець 3 ним познайомиться ближче. 
У локалізаціях відеогри «Dota 2» за допомогою методу суцільної вибірки були проаналізовані імена всіх ігрових персонажів. Необхідно зазначити, що в україномовній версії відеогри на екрані вибору персонажів можна побачити англомовні назви. Проте, якщо зайти на сторінку певного персонажа, то там, в розділі їхнього опису і навичок ми і можемо побачити українські вер сії їх ніх імен. Нами був проаналізовані використані способи перекладу імен персонажів на адекватність.

Перший спосіб перекладу, що використовувався під час пер едачі власних назв, це транскрипція - передача звуків мови системою знаків, відмінних від пр ийнятих в цій мові письмових одиниць (Гиляревский 13). Метою цього методу $є$ не стільки точна передача звуків мови оригіналу, скільки точне дотр имання взаємно однозначної відповідності між фонемами оригіналу і їхніми гр афіч ними відповідниками мови перекладу. У «Dota 2» наразі існує 119 ігрових героїв, водночас метод транскрибування був використаний у третині з них (33 зі 119).

Наприклад, Tiny - Taŭнi, Earthshaker-Eрсшейкер, Meеро - Mino, Weaver Biвер, Bane-Бейн, Necrophos-Hекрофос та ін.

Очевидним плюсом такого перекладу є можливість зберегти звучання імені мови оригіналу i, у такий спосіб, передати його колорит. Проте, тут криється i небезпека. Кожне із зазначених вище імен $є$ промовистим і несе в собі інфор мацію про персонажа. Наприклад, ім'я героя Tiny з англійської можна буквал ьно пер екласти як крихітний. Тут вбачається гр смислів. Цей герой розпочинає гру у вигляді невеликого людиноподібного уламка каменю і з часом та отр иманими навичками він змінюється, збільшується аж до велетенських розмірів. Цей момент і обігрується в його імені, але ніяк не передається під час перекладу. Подібні випадки втрати смислів є константними і для більшості інших персонажів, чиї імена були перекладені у такий спосіб.

Часом у процесі перекладу імен за допомогою транскрибування (2/33) лексеми у словосполученнях передавалися за допомогою калькування: Faceless Void - Безликий Войд, Nyx Assassin - Убивця Нікс, що додавало додаткових ознак персонажу.

Другим способомперекладу онімів у відеогрі є транслітерація - передача тексту, написаного за допомогою однієї алфавітної системи, засобами іншої алфавітної системи [Ахманова О. С. Словарь лингвистических терминов 470]. Ї̈ перевагою є можливість передачі письмової форми слова мови оригіналу з мінімальними викривленнями. Цей метод був популярним у XVIII-XIX століттях, коли знайомство з носіями іноземної культури було складнішим, ніж зараз, а тому замінювалося на прочитання літератури. Примітно, що подеколи під час перекладу якогось імені могла бути використана водночас і транслітерація, і транскрибування (Sven - Cвен, Riki-Piкi, Mirana-Mipaнa тощо). До транслітера ції пер екладачі звернулися у 18 випадках. Для прикладу можемо навести: Io - Io, RazorРазор, Pugnа-Пугна, Gyrocopter-Iірокоптер, Slardar-Cлардар та інші.

Третім способом перекладу власних назв $€$ калькування, тобто буквальний переклад іншомовного слова або частини слова. Таким прийомом пер екл адачі скористалися під час перекладу 50 імен героїв, тобто більш ніж будь-яким 
іншим способом перекладу. Це можна пояснити промовистістю імен персонажів гри, які найчастіше доносять до гравця певну інформацію про героя, опису ють його особливість, обігрують його зовнішність, дотичні до його істор ії то що. Для адекватного перекладу імені такі моменти повинні бути теж пер едані.

Як приклади вдалого використання калькування можна назвати такі власні назви: Silencer - Знемовлювач, Lifestealer - Життєкрад, Night Stalker - Hічний Мисливець, Spirit Breaker-Bинищувач духів, Wraith King - Kороль-дух, Crystal Maiden - Кришталева Діва, Dark Seеr- Темний Провидець, Dark Willow - Темна Bерба, Bristleback-Голкоспин та ін.

На прикладі перекладу кількох власних назв можна зрозуміти, яка саме інформація про оригінального персонажа була збережена під час пер екладу. Кожен із героїв «Dota 2» має в своєму арсеналі декілька заклинань, які він може використовувати. Одна із механік гри - це можливість деяких героїв заборон яти іншим використовувати їхні заклинання, називається Silence, що було пер екладено українською як Знемовлення. Silencer $\epsilon$ персонажем, ім'я якого репр езентує його основну особливість, тому, на нашу думку доцільніше було б йменувати персонажа Знемовлювач, на кшталт, англійських Silence i Silencer.

Iм'я іншого героя, Lifestealer, теж пов'язано з його ігровими здібностями. 3 кожною атакою герой не лише наносить ворогу шкоду, але й лікується у процентному співвідношенні від максимального здоров'я супротивника. Основна сила цього героя полягає у механіці крадіжки життя (що також стосується істо piї пер сонажа). Отже, і калькування Lifestealer як Життєкрад, яке повністю передає всю необхідну інфор мацію про героя, стає адекватним способом пер екладу.

Зафіксовані й випадки поєднання калькування з іншими методами. Напр иклад Faceless Void було перекладено як Безликий Boйд, тобто поєднанням калькування і транскрибування,що, на нашу думку, $є$ доцільним.

Цікавим випадком є переклад власної назви Treant Protector-Eнm-захисник. Енти - це істоти 3 міфології Дж. Р. Р. Толкіна, але в 70-х роках намаганнями копірайтерів використання цього слово в відеоіграх було заборонено. Отже, замість англійського «Ent», почали використовувати «Treant». Цей персонаж $є$ алюзією згаданих істот (а саме Древлена з «Володаря Перснів»), тому ім’я в локалізації, за нашим переконанням, йому підходить навіть краще, ніж оригінальне.

На жаль, ми вбачаємо неадекватний переклад у передачі деяких власних назв. Наприклад, Beastmaster було передано як Звіромайстер, хоча Повелитель Звірів в українському перекладі звучало б набагато краще. Ім'я персонажа Omniknight було перекладено як Лищар, водночас морфера Omni- була випущена. Sand King, замість очевидного варіанта Король Пісків, був іменований Царем Пісків, що додає йому абсолютно зайвого слов'янського колориту. Outworld Devourer - персонаж, який, виходячи з його життєпису, $є$ передвісником майбутніх катастр оф, має назву Потойбічний Смертежер, що не відповідає основній ознаці персонажа. Ім'я героя Storm Spirit, який є духом бурі, теж має неадекватний переклад. Штормовий Дух, з яким ми маємо справу в українській локалізації, повинен бути Духом Бурi, тому зміна частини мови (іменник storm прикметником) $\epsilon$ помилкою, оскільки це не $\epsilon$, наприклад, рисою характеру. Т а- 
кий спосіб перекладу не є винятком у цій локалізації (наприклад, Void SpiritПорожнечій Дух та Earth Spirit- Земний Дух). До того ж, поняття «шторм» стосується моря, а з опису персонажа стає ясно, що створювати сильну непогоду він може як мінімум на суші, для чого краще підійде слово «буря». Подібних пр икладів $є$ ще достатньо.

Наступним найпопулярнішим способом перекладу власних назв є транспозиція або ж принцип етимологічної відповідності. Під час його використання перекладач відшукує власне ім'я з онімічного фонду мови пер екладу, яке має спільну етимологію з ім'ям мови оригіналу. Тобто, імена в різних мовах, які мають одне походження, але розрізняються за формою, використовуються для передачі одне одного. Такий спосіб перекладу стає у нагоді під час пер екл аду історичних, біблійних, міфологічних власних назв.

У цій локалізації ми можемо зустріти 8 таких випадків. «Dota 2» не є сюжетно орієнтованою грою, але мати непогано промальований всесвіт їй це не заважає. У грі вбачається безліч алюзій та ремінісценцій: від давньогрецької міфології (ігрові предмети Рука Мідаса, Дедал та ін.) до художніх світів Г. Лавкрафта (репліки деяких персонажів, предмет Некрономікон тощо). Сер ед пер сонажів гри ми можемо зустріти знайомі імена: верховний бог Олімпу Zeus Зевс, римський бог війни Mars - Mapc, міфологічний птах, який циклічно пер ероджується Phoenix - Фенікс, одна з сестер Горгон Medusa - Медуза, чий погляд перетворює живих створінь у камінь та інші. Хоча життєпис у пер сонажів гри є унікальним, однак він перегукується із міфопоетикою оригіналів.

Ще одним способом у нашій класифікації є звернення до контекстуальної заміни. Перекладач під час перекладу підбирає для оригінальної власної назви таке слово або словосполучення, яке не $\epsilon$ його словниковим відповідником, але підібрано з урахування контексту вживання. Зазвичай, до цього методу звер таються, коли не один із вказаних вище способів не дасть потрібного ефекту.

У локалізації відеогри було знайдено 9 таких випадків. Серед вдалих спроб констатуємо: Snapfire - Запальниия, Arc Warden - Biдколотий уламок, Disruptor Буретворець та ін. Отримані під час перекладу імена героїв вдало відбивають ключові моменти їхньої історії, ігрові здібності тощо, які було закладено у власні назви мови оригіналу.

У локалізації констатуємо невдалі спроби еквівалентного перекладу. Напр иклад, Bounty Hunter, який номінується Головорізом в україномовній версії гри. Bounty Hunter - це історичне явище, так називали людей, чиєю пр офесією було за винагороду ловити злочинців-втікачів. Такою $є$ і професія цьо го гер оя . Незрозумілим є вибір слова «головоріз», лексема, що презентує зазвичай негативного персонажа, бандита або вбивцю, коли в український мові $є$ потрібний еквівалент «мисливець за головами», яким і називають людей цієї професії.

Необхідно звернути увагу й на інші власні назви, переклад яких здійснений з неточностями. Імена героїв Legion Commander, Timbersaw, Ember Spirit, Witch Doctor, Warlock та деяких інших персонажів зовсім не були адаптовані. Абсолютно незрозуміло подібне упущення, оскільки, щонайменше, частину цих імен адаптувати дуже просто. Найменування Warlock зустрічається і в інших 
відеоіграх і перекладається як Чорнокнижник, що повністю відповідає суті цього персонажа. Legion Commander має бути Командиром Легіону, Ember Spirit може номінуватися Духом Полум'я, що не було б відхиленням від основного значення. Замість імен, в описі цих персонажів фігурують слова «він», «в она», «герой» або ж речення змінюється у такий спосіб, щоб уникнути необхідності вживання власної назви. Наприклад, «Timbersaw fires a chain that embeds itself in the first tree it hits, pulling him towards it» було перекладено як «Випускає ланцюг, який зачіпляється за перше ліпше дерево і притягує до нього героя». Крім того, подібне уникання згадування імен персонажів є загальною рисою цієї локалізації. Випадки, на кшталт наведеного вище, є доволі частими. Сама суть тексту оригіналу при цьому, зазвичай, доноситься адекватно, але зберігається факт пропущення імені.

3 деякими персонажами проблема абсолютно протилежна. На сторінці оп ису цих героїв ми можемо бачити декілька варіантів їхніх імен. Underlord - це і Підземний лорд, і Андерлорд, а Viper - Вайпер і Гадюка. Звичайно, інтуїтивно зрозуміло, що йдеться про одного і того самого персонажа, але подібне по двоєння імені є неприпустимим під час перекладу.

Окрім зазначених недоліків, $є$ декілька випадків, коли не був дотр иманий принцип благозвуччя, тобто отримане ім'я не звучить пр иродно мовою пер екладу. Тут варто згадати Outworld Devourer- Потойбічний Cмертежер та Windranger-Bimpoгонка. Ім'я останньої героїні взагалі є застарілим. Це пер еклад більш раннього Windrunner, яке розробники змінили чер ез пр облеми з автор ськими правами.

Отже, українська локалізація «Dota 2» часом виглядає дещо незакінченою $\mathrm{i}$ має свої вагомі недоліки, проте, загалом, виконана на прийнятному рівні. Найпошир енішим способом перекладу власних назв у локалізації було калькування, що пояснюється промовистістю багатьох із них. Значна частина героїв має адекватно перекладені імена, а ті, що під час перекладу дещо спотворені, не наносять грі значної шкоди. Як уже зазначалося, «Dota 2 »е $\epsilon$ сюжетно ор ієнтованою грою, тому більшість гравців можуть і не знати, що у кожного із героїв $\epsilon$ власна історія і що оніми не $\epsilon$ випадковими. Отож, справжнім ігроманам, які ретельно вивчають життєпис кожного персонажа і шукають прихований сенс імені, варто використовувати оригінальну версію гри. Проведений нами аналіз висвітлює питання перекладу власних назв у відеоіграх, оскільки з огляду на розвиток ігрового контенту зростає попит на якісний переклад локалізацій відеоігор українською мовою, що зумовить подальші розробки окресленої нами пр облеми.

\section{Література}

1. Ахманова О. С. Словарь лингвистических терминов. Москва: Советская Энциклопедия, 1966. $608 \mathrm{c}$.

2. Гиляревский Р. С. Иностранные имена и названия в русском тексте. Москва: Высшая школа, 1985. $303 \mathrm{c}$.

3. Подольская Н. В. Словарь русской ономастической терминологии. Москва: Наука, 1988. $192 \mathrm{c.}$ 
4. Рюкова А. Р., Филимонова Е. А. Перевод имён собственных при локализации мультиплатформенных компьютерных игр. Вестник Башкирского Университета. 2016. Т. 21. № 4. C. 968-973.

5. 2019 Essential Facts About the Computer and Video Game Industry. URL: theesa.com/wpcontent/uploads/2019/05/ESA_Essential_facts_2019_final.pdf (дата звернення: 14.09.2020).

6. 2019 Year In Review Digital Games and Interactive Media. URL: superdataresearch.com/ 2019-year-in-review/ (дата звернення: 14.09.2020).

7. Завершено українську локалізацію Dota 2. URL: playua.net/zaversheno-ukrayinsku-lokalizatsiyu-dota-2/ (дата звернення: 14.09.2020).

8. Schäler R. «Localization». In: Routledge Encyclopedia of Translation Studies, Baker M. and Saldanha G. (Eds.), second edition. 2007. P. 157-161.

\section{Список джерел}

Dota 2, ver. 7.27. URL: store.steampowered.com/app/570/Dota_2/

\section{References}

1. Ahmanova O.S. Slovar' lingvisticheskih terminov (Dictionary of linguistic terms). Moskva: Sovetskaya Enciklopediya, 1966. 608. Print.

2. Gilyarevskij R. S. Inostrannye imena i nazvaniya v russkom tekste (Foreign names and titles in Russian text). Moskva: Vysshaya shkola, 1985. 303. Print.

3. Podol'skaya N. V. Slovar' russkoj onomasticheskoj terminologii (Dictionary of Russian onomastic terminology). Moskva: Nauka, 1988. 192. Print.

4. Ryukova A. R., Filimonova E. A. Perevod imyon sobstvennyh pri lokalizacii mul'tiplatformennyh komp'yuternyh igr (Translation of proper names when localizing multiplatform computer games). Vestnik Bashkirskogo Universiteta. 2016. T. 21. № 4. 968-973. URL: cyberleninka.ru/article/n/perevod-imen-sobstvennyh-pri-lokalizatsii-multiplatformennyh-kompyuternyh-igr/viewer

5. 2019 Essential Facts About the Computer and Video Game Industry. URL: theesa.com/wpcontent/uploads/2019/05/ESA_Essential_facts_2019_final.pdf

6. 2019 Year In Review Digital Games and Interactive Media. URL: superdataresearch.com/ 2019-year-in-review/

7. Zaversheno ukrayins'ku lokalizatsiyu Dota 2. URL: playua.net/zaversheno-ukrayinsku-lokalizatsiyu-dota-2/

8. Schäler R. "Localization". In: Routledge Encyclopedia of Translation Studies, Baker M. and Saldanha G. (Eds.), second edition. 2007. 157-161. Print.

\section{List of Sources}

Dota 2, ver. 7.27. URL: store.steampowered.com/app/570/Dota_2/ 
THE TRANSLATION PECULIARITIES OF PROPER NAMES IN A VIDEOGAME «DOTA 2»

\section{Tetiana Kushnirova}

Germanic Philology and Translation Department, National University "Yuri Kondratyuk Poltava Polytechnic", Poltava, Ukraine.

\section{Maksym Domarenko}

Germanic Philology and Translation Department, National University "Yuri Kondratyuk Poltava Polytechnic", Poltava, Ukraine.

\section{Abstract}

Background: In our rapidly globalizing world video games require high-quality localization for variety of recipient cultures. Such task may cause different problems. One of them is a translation of proper names into various languages. This article gives an insight into this problem through an analysis of Ukrainian localization of Dota 2, specifically the translation of proper names of its playable characters.

Purpose: is to review and demonstrate methods, which may be used to translate proper names in video games, as well as to show mistakes made by translators performing such task and give an evaluation to the quality of an existing localization.

Results: The analysis presented in this article shows how transcription, transliteration, calquing, transposition and contextual substitution were used to translate proper names of playable characters in Dota 2. Alongside with examples of successful translation, it also demonstrates numerous mistakes such as: loss of important information meant to be conveyed, examples of proper names that violate the principles of euphony, etc.

Discussion: Given analysis sheds some light on methods used to translate proper names and accompanying problems. Nevertheless, more researches should be performed in order to review numerous existing Ukrainian localizations of other games with an end goal to provide the knowledge required to improve future ones.

Keywords: Dota 2, localization, videogame, proper names, transcription, transliteration.

Vitae. Tetiana Kushnirova is a Doctor of Philology, Professor of Germanic Philology and Translation Department at National University "Yuri Kondratyuk Poltava Polytechnic". Her areas of research interests include literary theory, literary history, literary translation.

Correspondence: kuta2608@gmail.com

Vitae. Maksym Domarenko is a Master's student of Germanic Philology and Translation Department at National University "Yuri Kondratyuk Poltava Polytechnic". His areas of research interests include linguocultural studies, translation and interpretation studies.

Correspondence: wigglyfern@gmail.com

Надійшла до редакціії 02 жовтня 2020 року. Рекомендована до друку 19 жовтня 2020 року. 